\title{
Biocontrol features in an indigenous bacterial strain isolated from agricultural soil of Gujarat, India
}

\author{
K. Parikh and A. Jha* \\ Ashok and Rita Patel Institute of integrated Study and Research in Biotechnology and Allied Sciences, New \\ Vallabh Vidyanagar, Anand- 388121 (Gujarat), INDIA. "Corresponding author: alka_mishra2k@yahoo.com
}

\begin{abstract}
The present investigation was carried out to test the biocontrol potential of a phosphate solubilizing bacterial strain, LK11 isolated from mungbean rhizosphere, in Gujarat, India. This strain besides solubilizing the insoluble $P$ also demonstrated inhibition of Sclerotium rolfsii growth in agar plate and produced a volatile compound, HCN. During in vitro studies LK11 inhibited sclerotia germination by $40 \%$. The most important contributing factor towards increased mungbean growth by reducing fungal attack was the enhanced production of antifungal compounds like PAL (47 mM/ml/mg of tissue), phenolics $(90.2 \mu \mathrm{g} / \mathrm{ml} / \mathrm{mg})$ and flavonoids $(184.2 \mathrm{mg} /$ $\mathrm{ml} / \mathrm{g}$ ) which is comparable to earlier reports available. Testing the efficiency of this strain in consortium culture alongwith some other PGPR strains and biocontrol microbes at multilocational fields is in offing.
\end{abstract}

Keywords: PSB, Biocontrol, PAL, phenolics, S. rolfsii. 


\section{Introduction}

Biofertilizers are organisms that enrich the nutrient quality of soil. A group of bacterial population closely associated with rhizosphere region of soil is known as plant growth promoting rhizobacteria (PGPR) and is mainly involved in enhancing plant growth by several activities. Such plant growth promotion may be achieved via one or more direct/indirect mechanisms such as phosphate solubilization, nitrogen fixation, biocontrol and production of plant growth regulators etc.

Phosphorus (P) is second essential macronutrient next to nitrogen which is most commonly limiting the growth of crops and is applied to soil in the form of phosphatic fertilizers. Plants acquire P from soil solution as phosphate anions. However, phosphate anions are extremely reactive and may be immobilized through precipitation with cations such as $\mathrm{Ca}^{2+}, \mathrm{Mg}^{2+}, \mathrm{Fe}^{3+}$ and $\mathrm{Al}^{3+}$, depending on the $\mathrm{pH}$ of soil. As a result, the amount available to plants is usually a small proportion of this total P (Rodriguez et al., 1999; Anamika et al., 2007). Phosphate solubilizing bacteria (PSB) can serve as an alternative that can be efficiently developed as biofertilizers, as they support plant growth by solubilizing organic and inorganic phosphates. Several Phosphate solublizing bacteria such as Pseudomonas putida, Pantoea agglomerans, Azotobacter spp., Bacillus subtilis, Rhizobium spp., P. fluorescens, P. cepacia and Aeromonas vaga have been studied extensively (Srivastava and Shalini, 2009; Jha et al., 2011).

Pathogenic microorganisms affecting plant health are a major and chronic threat to food production and ecosystem stability worldwide. Mung bean (Vigna radiata), an important legume, is highly susceptible to the attack of a fungal pathogen, Sclerotium rolfsii. It primarily attacks host stems. The first signs of infection, though usually undetectable, are dark-brown lesions on the stem at or just beneath the soil level (Yaqub and Shahzad, 2011). Also, there are number of fastidious diseases for which chemical solutions are few, ineffective, or nonexistent. Biological control is thus being considered as an alternative or a supplemental way of reducing the use of chemicals in agriculture (Compant et al., 2005). PGPR strains have been studied for decades for their plant growth-promoting effects through effective suppression of soil borne plant diseases through siderophore-mediated competition for iron, antibiosis, production of lytic enzymes, and induced systemic resistance (ISR) (Mamaghani et al., 2009). ISR is mediated through production of several defense compounds in plants such as phenolics and PAL (Phenylalanine Ammonia Lyase) and other secondary metabolites. There has been a large body of literature describing potential uses of plant associated bacteria as agents stimulating plant growth and managing soil and plant health, but an efficient strain in terms of both fertilization and biocontrol potential has been lacking. Further very few reports are available in the direction of PSB inoculant application for the growth of mung bean (Jha et al., 2011) and protecting it from the attack of devastating pathogen like $S$. rolfsii. With the aim of developing a phosphate inoculant that would decrease the severity of pathogen attack to mung bean and would promote the overall plant growth, the present investigation was carried out. The bacterial strain has been isolated from the rhizosphere of Mung bean cultivated in agricultural fields located in nearby areas of Vadodara, Gujarat, India. The objective of this study was to evaluate the effect of PSB strain as biocontrol agent for mung bean plants. 


\section{Materials and methods}

Phosphate solubilizing bacterial strains were isolated from soil samples (collected from different mung bean fields near Vadodara, Gujarat, India) in a selective media PAMR (Pikovskaya's agar containing 1\% Methyl Red). Out of 16 bacterial strains, the strain LK11 showing good solubilization zone was picked up and purified further and stored on PAMR slants at $4^{\circ} \mathrm{C}$ for further use. It was point inoculated on PAMR plates and incubated at $30 \pm 2^{\circ} \mathrm{C}$ for 5 days. The size of the halo/clear zones around the colonies showing phosphate solubilization was noted. Solubilization efficiency was calculated according to Nguyen et al. (1992) as given below:

Solubilization efficiency $(E)=\underline{\text { Diameter of solubilization zone (S) }}$ X 100 Diameter of the colony

Soluble $\mathrm{P}$ was also estimated in $100 \mathrm{ml}$ NBRIP broth inoculated with LK11 according to the method of Nautiyal et al. (1999).

Biocontrol potential of LK11 was assessed by both in vitro and in planta studies against the pathogen, S.rolfsii in mung bean. In vitro antifungal activity was demonstrated through direct inhibition of fungal growth in agar plate, $\mathrm{HCN}$ production and inhibition of fungal spore germination by LK11. Dual culture Plate Technique (Ganesan and Gnanamnickam, 1987) was followed where a sclerotium of S. rolfsii was placed in the center of a fresh PDA plate. Mid log phase bacterial culture was point inoculated in PDA plate at a distance of $3 \mathrm{~cm}$ from the center. A control plate was also prepared which contained the sclerotium of test pathogen only. The plates were incubated at $30 \pm 2^{\circ} \mathrm{C}$ and were observed after 5 days.

Test for $\mathrm{HCN}$ production was carried out by spectrophotometric and inverted plate methods. In spectrophotometric method $18 \mathrm{hrs}$ old bacterial culture was centrifuged at $7000 \mathrm{rpm}$ for $15 \mathrm{~min}$ at $4^{\circ} \mathrm{C}$. The supernatant was passed through $0.2 \mu$ filter; then $2 \mathrm{ml}$ O-phosphoric acid was added and observed for development of pink color. The absorbance was read at $530 \mathrm{~nm}$. Inverted plate technique was performed following the standard method (Fernando et al., 2005). The bacterial culture was streaked on NA plate and inverted over the PDA plate containing sclerotium in the centre and then incubated at $30 \pm 2^{\circ} \mathrm{C}$ for 5 days.

In vitro sclerotia germination was studied by placing a drop of mid log phase bacterial culture on sclerotium of $S$. rolfsii and mixed well. Sclerotia mixed in sterile distilled water only served as control. The slides were placed in moist chambered Petri plates and incubated at $25 \pm 2^{\circ} \mathrm{C}$ for 15 days (Srivastava and Shalini. 2009). All experiments were conducted in triplicate. Sclerotia germination was observed under binocular microscope.

The biocontrol activity of LK11 against $S$. rolfsii was checked in mung bean plants. For this investigation, mung seeds were surface sterilized (in $0.1 \%$ $\mathrm{HgCl}_{2}$ for $3 \mathrm{~min}$ ), coated with 1\% CMC (Carboxy Methyl Cellulose) and fresh bacterial culture filtrate and kept for air drying. Then the seeds were challenged with fungal mycelia and kept on 3\% water agar tubes for germination at ambient temperature $\left(20-26^{\circ} \mathrm{C}\right)$. Seeds coated with CMC and fungal mycelia served as control. Observations were recorded after 7 days.

Plant defense mechanism produces some enzymes, phytoalexins and phenolic compounds during fungal attack. Therefore, the assay of 2 important compounds viz., phenolics and flavonoids (antioxidant) and an enzyme PAL was performed. For PAL assay $0.5 \mathrm{~g}$ fresh leaf tissues of mungbean plant were homogenized in 2 $\mathrm{ml}$ of $0.1 \mathrm{M}$ sodium phosphate buffer, $\mathrm{pH} 7.0$ at $4^{\circ} \mathrm{C}$. The homogenate was centrifuged for $20 \mathrm{~min}$ at 12,000 rpm. Supernatant served as a crude protein extract and was used for the estimation of PAL activity (Anand $e t$ al., 2007). PAL activity was determined as the rate of 
conversion of L-phenylalanine to trans-Cinnamic acid at $290 \mathrm{~nm}$ as described by Dickerson et al. (1984) with minor modifcations. The assay mixture consisted of $200 \mu \mathrm{l}$ crude protein extract and $1800 \mu \mathrm{l}$ of $6 \mu \mathrm{M} 1-$ phenylalanine in $1000 \mu \mathrm{l}$ of $500 \mathrm{mM}$ Tris- $\mathrm{HCl}$ buffer (pH 8.5). The mixture was incubated at $37^{\circ} \mathrm{C}$ for $1 \mathrm{~h}$ and absorbance was measured at $290 \mathrm{~nm}$. Enzyme activity was expressed on a fresh weight basis as nmol trans-cinnamic acid $\mathrm{min}^{-1} \mathrm{mg}^{-1}$ protein $\left(\mathrm{nMol} \mathrm{min}{ }^{-1} \mathrm{mg}^{-}\right.$ $\left.{ }^{1}\right)$. Phenolics estimation was done in $1 \mathrm{~g}$ root samples that were homogenized in $10 \mathrm{ml}$ of $80 \%$ methanol and agitated for $15 \mathrm{~min}$ at $70{ }^{\circ} \mathrm{C}$ (Zieslin and Ben-Zaken, 1993). One $\mathrm{ml}$ of the methanolic extract was added to $5 \mathrm{ml}$ of distilled water (d.w) and $250 \mu$ l of FolinCiocalteau reagent $(1 \mathrm{~N})$ and the solution was kept at $25^{\circ} \mathrm{C}$. The absorbance of the developed blue color was measured using a spectrophotometer at $725 \mathrm{~nm}$. Phenol crystal was used as the standard. The amount of phenolics was expressed as $\mu \mathrm{g}$ Phenol crystal $\mathrm{mg}^{-1}$ protein. Total flavonoid content was measured by aluminium chloride colorimetric assay (Marinova et al., 2005). 1 $\mathrm{ml}$ of methanolic extract (as stated above) was added to $10 \mathrm{ml}$ volumetric flask containing $4 \mathrm{ml}$ of d.w. To the above mixture, $0.3 \mathrm{ml}$ of $5 \% \mathrm{NaNO}_{2}$ was added. After 5 minutes, $0.3 \mathrm{ml}$ of $10 \% \mathrm{AlCl}_{3}$ was added. At $6^{\text {th }} \mathrm{min}$, $2 \mathrm{ml}$ of $1 \mathrm{M} \mathrm{NaOH}$ was added and the total volume was made up to $10 \mathrm{ml}$ with d.w. The solution was mixed well and the absorbance was measured against reagent blank at $510 \mathrm{~nm}$. Standard graph was prepared with different concentration of gallic acid and the flavonoid content was expressed as $\mathrm{mg} / \mathrm{ml} / \mathrm{g}$.

\section{Results and discussion}

LK11 is a Gram negative, cocci that forms white coloured smooth colony in agar plate. It gave a solubilization zone on PAMR plate (solubilization efficiency$200 \%$ ). When tested in NBRIP medium it was able to release 25 ppm soluble $P$.

The results of experiments for testing the biological control ability of LK11 were satisfying and to our surprise, it could fastidiously suppress the growth of S. rolfsii up to $38.0 \%$ in the dual culture plate after 5 days of incubation. It indicates that the bacteria caused a significant inhibition. Ingle et al. (2010) recorded maximum inhibition of $S$. rolfsii $(62.6 \%)$ by PGPR isolate CORb-9. The bacteria utilize several mechanisms for inhibiting fungal growth. Besides fungal inhibition in direct contact, LK11 also stopped sclerotium germination altogether in comparison to control (5.2 cm mycelia growth) in inverted plate method. The reason might be the production of $\mathrm{HCN}$ (a volatile compound) which was confirmed by development of pink color on reaction with o-phosphoric acid. Hayat et al. (2010) also reciprocated the same opinion about involvement of $\mathrm{HCN}$ in antifungal mechanisms. During in vitro studies it was found that in presence of LK11, the $S$. rolfsii spores exhibited 2 different patterns of germination i.e. hyphal and eruptive, which are characteristics of the sclerotial germination (Figure 1). Eruptive type of germination dominated the hyphal type, whereas, one sclerotium just broke without production of any mycelia. It is inferred from the results that there was remarkable $40 \%$ inhibition of sclerotia germination even after 15 days of incubation (Table 1). 


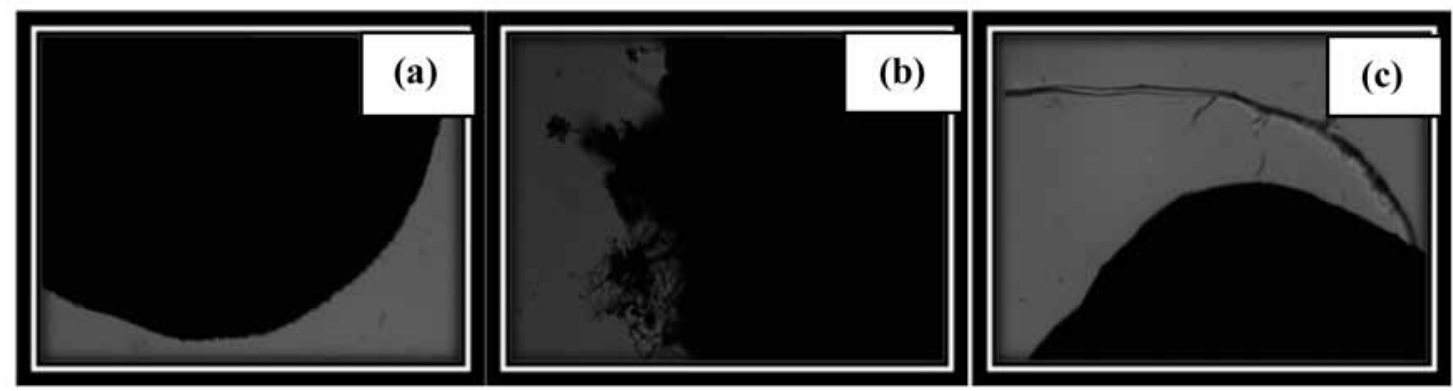

Figure 1. Sclerotia germination in presence of LK11 bacterial strain (a) Control sclerotia (b) eruptive germination and (c) hyphal germination of sclerotia.

Table 1. In vitro sclerotia germination in presence of LK11 bacterial strain

\begin{tabular}{lccc}
\hline \multirow{2}{*}{ Sclerotium Germination } & \multicolumn{3}{c}{ Incubation time } \\
\cline { 2 - 4 } & $\mathbf{5}$ days & $\mathbf{1 0}$ days & $\mathbf{1 5}$ days \\
\hline Hyphal & 0 & 1 & 1 \\
Eruptive & 1 & 3 & 4 \\
Broken sclerotia & 0 & 1 & 1 \\
Total & $1 / 10$ & $5 / 10$ & $6 / 10$ \\
$\%$ Germination & 10 & 50 & 60 \\
\hline
\end{tabular}

In planta studies in agar tubes showed magnificent results and limited the fungal invasion in mung bean plants. All the LK11 treated plants were able to germinate successfully in comparison to control where seeds could not germinate at all. After 7 days of growth LK11 treated plants attained a height of 14 $\mathrm{cm}$ with root length of $7 \mathrm{~cm}$ at 2 leaf stage. Though the plant resisted pathogen attack but few brown patches could be observed on shoot. Highest root colonization by $S$. rolfsii was observed in mung bean plants growing in soil artificially infested with sclerotia of S. rolfsii (Yaqub and Shahzad, 2011). Several changes are induced in plants during pathogen invasion which are manifested morphologically and physiologically. The treatment of mung bean with LK11 led to enhanced production of antifungal compounds that boosted up the plant defense against $S$. rolfsii. PAL is the first enzyme in phenylpropanoid metabolism and is involved in the synthesis of plant defense molecules phytoalexins and phenolics. In the present investigation, high induction of PAL activity (Figure 2) was noted in LK11 treated plants (47 $\mathrm{nM} / \mathrm{ml} / \mathrm{mg}$ of tissue) in comparsion to control $(5 \mathrm{nM} /$ $\mathrm{ml} / \mathrm{mg}$ of tissue). Ramamoorthy et al. (2002) noted maximum induction of PAL activity in $P$. fluorescens treated tomato roots after 4 days of inoculation with pathogen, $F$. oxysporum ( $45 \mathrm{nM} / \mathrm{ml} / \mathrm{mg}$ of tissue). Similarly, elevated levels of phenolics in plants are 
also observed during fungal attack. Accumulation of $90.2 \mu \mathrm{g} / \mathrm{ml} / \mathrm{mg}$ phenolics was observed in mung bean plants inoculated with LK11 strain in comparsion to control $(15 \mu \mathrm{g} / \mathrm{ml} / \mathrm{mg})$. Ramamoorthy et al. (2002) noted accumulation of $150 \mu \mathrm{g}$ phenolics/mg of tissue in tomato roots treated with $P$. fluorescens and pathogen $F$. oxysporum after 5 days. Flavonoids are the antioxidant compounds that indirectly act as antifungal agents. They are naturally present in low concentration in plants, but during pathogen invasion the elevated levels are seen. Plants treated with LK11 showed 2 folds increase in flavonoids concentration $(184.2 \mathrm{mg} / \mathrm{ml} / \mathrm{g})$ when compared with control $(90.3$ $\mathrm{mg} / \mathrm{ml} / \mathrm{g}$ ). It can be inferred that PSB helped the plant to produce flavonoids in sufficient amount to resist the pathogen attack.

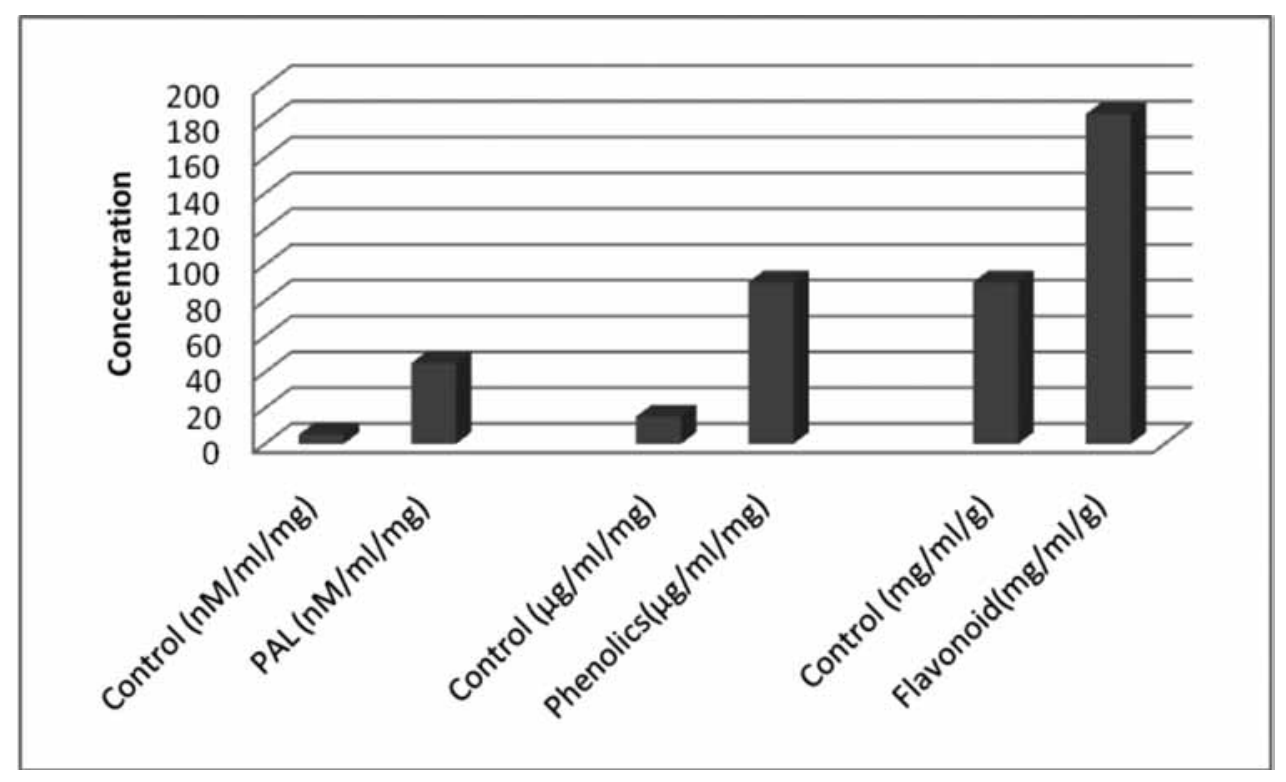

Figure 2. Production of antifungal compounds by mung bean during infection with $S$. rolfsii in presence of LK11.

\section{Conclusions}

The present investigation has revealed that the phosphate solubilising bacterial strain, LK11 has the potential to be applied in fields as a biocontrol agent for mungbean against its fungal pathogen $S$. rolfsii. Further, detail investigations of this strain are needed to present more conclusive results.

\section{Acknowledgements}

The authors acknowledge financial assistance and support given by CVM, ARIBAS, SP University, Anand, Gujarat, India. 


\section{References}

Anamika, Saxena, J., Sharma, V. 2007. Isolation of tri-calcium phosphate solubilizing strains from semi-arid agricultural fields of Rajasthan, India. J. Pure Appl. Microbiol. 1, 269-280.

Anand, T., Chandrasekaran, A., Raguchander, T., Prakasam, V., Samiyappan, R. 2007. Chemical and biological treatments for enhancing resistance in chilli against Colletotrichum capsici and Leveillula taurica. Arch. of Phytopathol. Plant Protect. 1, 1-19.

Compant, S., Duffy, B., Nowak, J., Clément, C., Barka, E. A. 2005. Use of Plant Growth-Promoting Bacteria for Biocontrol of Plant Diseases: Principles, Mechanisms of Action, and Future Prospects. Appl. Environ. Microbiol. 71, 4951-4959.

Dickerson, D. P., Pascholati, S. F., Hagerman, A. E., Butler, L. G., Nicholson, R. L. 1984. Phenylalanine ammonia-lyase and hydroxycinnamate: $\mathrm{CoA}$ ligase in maize mesocotyls inoculated with $\mathrm{Hel}$ minthosporium maydis or Helminthosporium carbonum. Physiological Plant Pathol. 25, 111-123.

Fernando, W.G. D., Ramarathnam, R., Krishnamoorthy, A. S., Savchuk, S. C. 2005. Identification and use of potential bacterial organic antifungal volatiles in biocontrol. Soil Biol. Biochem. 37, 955-964.

Ganesan, P., Gnanamnickam, S.S. 1987. Biological control of Sclerotium rolfsii Sacc. in peanut by inoculation with P. fluorescens. Soil Biol. Biochem. 19, 35-38.

Hayat, R., Ali, S., Amara, U., Khalid, R., Ahmad, I. 2010. Soil beneficial bacteria and their role in plant growth promotion. Ann. Microbiol. 60, 579598.

Ingle, R.W., Deshmukh, V.V. 2010. Antifungal activity of PGPR and sensitivity to Agrochemicals. Ann. Plant Protection Sci. 18, 451-457.
Jha, A., Sharma, D., Saxena, J. 2011. Effect of single and dual phosphate solubilizing bacterial strain inoculations on overall growth of mung bean plants. Arch. Agronomy Soil Sci., (1-15).

Karthikeyan, Jaleel, C.A., Azooz, M.M. 2009. Individual and combined effects of Azospirillum brasilense and Pseudomonas fluorescens on Biomass Yield and Ajmalicine Production in Catharanthus roseus. Academic J. Plant Sci. 2, 69-73.

Mamaghani, V. F., Ahmadzadeh, M., Sharifi, R. 2009. Screening systemic resistance-inducing Fluorescent peudomonads for control of bacterial blight of cotton caused by Xanthomonas campestries pv. Malvacearum. J. Plant Pathol. 91, 663-670.

Marinova, D., Ribarova, F., Atanassova, M. 2005. Total phenolics and total flavonoids in Bulgarian fruits and vegetables. J. Univ. Chem. Technol. Metallurgy. 40, 255-260.

Nautiyal, C. S. 1999. An efficient microbiological growth medium for screening phosphate solubilizing microorganisms. FEMS Microbiol. Lett. 170, 265-270.

Pandey, A., Palni, L.M.S. 1998. Isolation of Pseudomonas corrugate from Sikkim Himalaya. World J. Microbiol. Biotechnol. 14, 411-413.

Ramamoorthy, V., Raguchander, T., Samiyappan, R. 2010. Induction of defense-related proteins in tomato roots treated with Pseudomonas fluorescens Pf1 and Fusarium oxysporum f. sp. lycopersici. J. Soil Sci. Plant Nutr. 10, 407 - 413.

Rodriguez, H., Fraga, R. 1999. Phosphate solubilizing bacteria and their role in plant growth promotion. Biotechnology Adv.17, 319-339.

Shaharoona, B., Arshad, M., Zahir, Z.A. 2006. Effect of plant growth promoting rhizobacteria containing ACC-deaminase on maize (Zea mays L.) growth under axenic conditions and on nodulation in mung bean (Vigna radiata L.). Lett. Appl. Microbiol. 42, 155-159. 
Shrivastava, R., Shalini. 2009 Antifungal activity of Pseudomonas fluorescens against pathogenic fungi. The internet j. Microbiol. 7 (2).

Yaqub, F., Shahazad, S. 2011. Efficacy and persistence of micobial antagonists against Sclerotium rolfsii under field condition. Pak. J. Bot. 43, 2627-2634.
Zieslin, N., Ben-Zaken, R. 1993. Peroxidase activity and presence of phenolic substances in peduncles of rose flowers. Plant Physiol. Biochem. 31, 333339. 